\title{
URGENSI NOTARIS SYARI'AH DALAM BISNIS SYARI'AH DI INDONESIA
}

\author{
Laurensius Arliman S \\ Sekolah Tinggi Ilmu Hukum (STIH) Padang \\ e-mail: laurensius22@gmail.com
}

\begin{abstract}
The business development of the economy not only in the field of conventional, Shari'ah economic business now has started mushrooming everywhere. With a population of Indonesia is predominantly Muslim, the more it will attract market share to take part in business economics Shari'ah. Instead of that, the presence of a notary shari'ah is urgently needed in Indonesia, because the focus of work in the field of economics shari'ah, so it can ensure law and society in transacting shari'ah. The research used normative juridical approach, using the theory of legal certainty. So we get Analisia, that the reality is that the people do not feel comfortable in transacting Shari'ah, because of the absence of provisions on rules of shari'a law notary. So the conclusion is obtained, the need for Shari'ah notary very important.

Perkembangan bisnis ekonomi bukan hanya di bidang konvensional saja, sekarang bisnis ekonomi syari'ah sudah mulai menjamur dimana-mana. Dengan penduduk Indonesia yang mayoritas beragama Islam, maka akan semakin menarik pangsa pasar untuk mengambil bagian dalam bisnis ekonomi syari'ah. Dari pada itu, kehadiran notaris syari'ah sangat dibutuhkan di Indonesia, karena fokus kerjanya pada bidang ekonomi syari'ah, sehingga bisa menjamin kepastian hukum dan masyarakat di dalam bertransaksi syari'ah. Penelitian ini menggunakan metode pendekatan secara yuridis normatif, dengan menggunakan teori kepastian hukum. Sehingga didapatkan analisia, bahwa dengan kenyataan yang ada, masyarakat belum merasa nyaman dalam bertransaksi syari'ah, karena belum adanya pengaturan tentang aturan hukum notaris syari'ah. Maka kesimpulan yang didapatkan, kebutuhan terhadap notaris syari'ah sangat penting.
\end{abstract}

Keywords: notary shari'ah; shari'ah business; Indonesia 


\section{A. Pendahuluan}

Krisis ekonomi yang terjadi saat ini telah berkembang menjadi krisis yang rumit dan kompleks yang terkadang menimbulkan pesimisme tentang jayanya ekonomi Indonesia di masa yang akan datang. Saat ini Indonesia berada dalam masa transisi, yang belum terbayangkan berapa lama masa transisi ini akan berlansung. Meskipun semula krisis ini hanya merupakan contagion effect dari depresiasi mata uang bath Thailand terhadap dollar AS pada tahun 1997, tetapi karena fundamental perekonomian Indonesia yang rapuh, maka dampak krisis ini terkena sangat dahsyat, sementara proses economic recovery-nya berjalan sangat lambat. Prestasi perekonomian Indonesia yang semula cukup baik, berubah menjadi negatif, banyak pengamat ekonomi Indonesia mengatakan bahwa pembangunan ekonomi Indonesia adalah semu dengan fundamental yang tidak kuat. Di samping itu, para pengamat juga mengatakan bahwa perekonomian Indonesia tidak didukung oleh sumber daya domestik yang tangguh, tetapi karena didukung oleh investasi asing, bahkan berjangka pendek yang sewaktu-waktu mereka dapat keluar Indonesia. Pembangunan nasional juga dibangun dengan utang luar negeri yang bersifat pasif, sehingga justru memberatkan kondisi perekonomian Indonesia untuk bangkit kembali.1

Kondisi perekonomian Indonesia sebagaimana tersebut di atas, telah menimbulkan berbagai problem sosial yang kompleks, misalnya timbul tingkat pengangguran yang tinggi, bertambahnya angka kemisikinan, produktivitas dan kualitas tenaga kerja yang rendah, serta merosotnya usaha kecil dan menengah yang menjadi tumpuan rakyat. Di samping itu, perkembangan ekonomi global yang bergerak dari satu negara ke negara lain secara bebas, sehingga terjadi ketidakpastian akses pasar ekonomi dunia. Kondisi perekonomian dunia seperti ini, membawa kecenderungan pada peningkatan perjanjian bilateral dan multilateral antarnegara selaku pelaku ekonomi di dunia internasional yang pada akhirnya berdampak pada timbulnya hukum baru pada masing-masing negara.

\footnotetext{
${ }^{1}$ Abdul Manan, Aspek Hukum dalam Penyelengaraan Investasi di Pasar Modal Syariah Indonesia (Jakarta: Kencana, 2009), h. 2.
} 
Hubungan hukum dengan ekonomi bukan hubungan satu arah, tetapi hubungan timbal balik dan saling mempengaruhi. Kegiatan ekonomi yang tidak didukung oleh hukum akan mengakibatkan terjadinya kekacauan, sebab apabila para pelaku ekonomi dalam mengejar keuntungan tidak dilandasi dengan norma hukum, maka akan menimbulkan kerugian salah satu pihak dalam melakukan kegiatan ekonomi. Ada sementara ahli hukum mengatakan bahwa hukum selalu berada di belakang kegiatan ekonomi, setiap kegiatan ekonomi dilakukan oleh seseorang, pasti kegiatan itu diikuti oleh norma hukum yang menjadi rambu pelaksananya. Hukum yang mengikuti kegiatan ekonomi ini merupakan seperangkat norma yang mengatur hubungan kegiatan ekonomi dan ini selalu dipengaruhi oleh sistem ekonomi yang dianut oleh suatu negara. Untuk Indonesia dasar kegiatan hukum ekonomi itu terletak pada UndangUndang Dasar Negara Republik Indonesia Tahun 1945 dan beberapa peraturan deviratif laiinnya. ${ }^{2}$

Perkembangan ekonomi syari'ah di Indonesia dalam sepuluh tahun terakhir ini mengalami kemajuan yang pesat, lebih-lebih setelah berdirinya beberapa lembaga keuangan yang berbasis syari'ah, sperti perbankan syari'ah, asuransi syari'ah, pasar modal syari'ah, hingga hotel syari'ah. Wacana sistem ekonomi syari'ah itu diawali dengan konsep ekonomi dan bisnis non-ribawi. Sebenarnya sistem ekonomi syari'ah mencakup semua aspek ekonomi. Namun, dewasa ini terkesan bahwa ekonomi syari'ah identik dengan konsep tentang keuangan dan perbankan. Kecenderungan ini dipengaruhi oleh dua faktor. Pertama, Tihan dalam al-Qur'an dan Sunnah yang paling menonjol adalah doktirn transaksi non-ribawi (larangan praktik riba). Kedua, peristiwa krisis minyak tahun 1974 dan 1979 yang menimbulkan kekuatan finansial berupa petrodollar pada negara-negara di Kawasan Timur Tengah dan Afrika Utara, termasuk Indonesia, Malaysia dan Brunei di Asia Tenggara. ${ }^{3}$ Kini eksistensi perbankan syari'ah tampak semakin dan menunjukkan perkembangan yang menggembirakan. ${ }^{4}$

\footnotetext{
2Ibid., h. 6.

${ }^{3}$ M. Dawan Rahadrjo, dalam Adiwarman Karim, Bank Isalam: Analisis Fiqih dan Keuangan (Jakarta: III T Indonesia, 2003), halaman pengantar. Bandingkan dengan M. Khabir Hasan dan Mervyn K. Lewis, Handbook of Islamic Banking (Great Britain: Edward Elgar Publisih Limited, 2007), h. 21-37.

${ }^{4}$ Adil, Mengenal Notaris Syari'ah (Bandung: PT. Citra Aditya Bakti, 2011), h. 1.
} 
Kehadiran sistem perekonomian syari'ah Indonesia dalam kurun waktu dua dasawarsa terakhir berkembang ${ }^{5}$ sangat pesat. Hal tersebu terlihat bukan hanya dalam lingkungan perbankan, melainkan juga tumbuh dalam berbagai bidang bisnis yang lain, seperti asuransi syari'ah, pegadaian syari'ah, pasar modal syari'ah dan lain-lain. Kondisi ini selain disebabkan sistem ekonomi konvensional ternyata tidak dapat memenuhi harapan, kesadaran umat islam untuk bersyari'ah secara käffah dalam pelbagai aspek kehidupan ternyata juga terus meningkat. 6

Terciptanya perekonomian yang stabil ini disebabkan sistem syari'ah dapat mengeliminasi dan melarang kegiatan-kegiatan yang non-produktif, haram, berbahaya, tidak baik dan spekultatif. Kondisi ini akan mendorong pada peningkatan pemanfaatan sumber daya, mengurangi tekanan inflasi, serta menanggulangi krisis ekonomi sehingga memudahkan pencapaian tujuan-tujuan ekonomi yang telah direncanakan. ${ }^{7}$

Perkembangan lembaga keuangan syari'ah pada satu sisi membanggakan, tetapi di sisi lain masih sangat memprihatikan karena belum didukung oleh instrument hukum yang memadai sebagaimana lembaga keuangan konvensional. Di antara instrumen hukum yang pada saat ini masih dirasa kurang memadai karena berbasiskan paradigm kontrak bisnis konvensional adalah bidang notaris.

Notaris adalah pejabat umum yang satu-satunya berwenang untuk membuat akta otentik mengenai semua pembuatan perjanjian dan penetapan yang diharuskan oleh peraturan umum atau oleh yang berkepentingan dikehendaki untuk dinyatakan dalam suatu akta otentik, menjamin kepastian terhadap tanggalnya, menyimpan aktanya dan memberikan grosse, salinan dan kutipannya, semua sepanjang akta itu oleh suatu peraturan umum tidak juga ditugaskan atau dikecualikan kepada pejabat atau orang lain. ${ }^{8}$

\footnotetext{
5Nur kholis, "Penegakan Syari'ah di Indonesia: Perspektif Ekonomi”, Jurnal Hukum Islam, Vol . 5, No. 1, 2006, h. 169-175.

6Tim Penyusun, Himpunan Fatwa Dewan Syariah Nasional MUI, Edisi Revisi Tahun 2006 (Jakarta: DNS MUI-BI, 2006), h. kata pengantar.

${ }^{7}$ Nurul Huda, et.al., Ekonomi Makro Islam, Pendekatan Teoritis (Jakarta: Kencana: 2008), h. 234. h. 2 .

8Laurensius Arliman S, Notaris dan Penegakan Hukum Oleh Hakim (Yogyakarta: Deepublish, 2015),
} 
Keberadaan notaris dalam kontrak bisnis termasuk bisnis syari'ah adalah sangat penting mengingat tugas pokoknya membuat akta otentik yang diperlukan sebagai alat bukti telah terjadinya peristiwa hukum. Sebagai pejabat umum pembuat akta otentik, notaris dituntut memiliki kepribadian yang baik, bekerja mandiri, jujur, tidak memihak (adil) dan penuh rasa tanggung jawab. Di samping itu, ia juga dituntut untuk memiliki kecakapan atau penguasaan dalam bidang hukum yang menjadi kompetensinya. Ini terutama selain karena ia harus cakap, ia juga dituntu untuk memberikan penyuluhan hukum kepada kliennya agar mencapai kesadaran hukum yang tinggi, yaitu menyadari dan menghayati hak dan kewajibannya. ${ }^{9}$

Mengingat keberadaan dan tugas notaris yang strategis dan penuh tantangan tersebut maka sudah semestinya seiring dengan perkembangan bisnis syari'ah yang semakin pesat, perlu segera digagas lahirnya notaris syari'ah, yaitu notaris yang memiliki kompetensi di bidang hukum perdata islam dan bisnis syari'ah. Urgensi keberadaan notaris syari'ah setidaknya didasarkan pada beberapa alasan berikut: 10

Pertama, hampir sebagian besar notaris yang ada saat ini tidak (atau belum) mengerti aspek teoritis dan praktik hukum bisnis syari'ah apalagi sebagain besar mereka berlatar belakang pendidikan sarjana hukum (S. H) dan magister kenotariatan (M. Kn);

Kedua, aspek hukum bisnis syari'ah banyak memilki perbedaan dengan bisnis konvensional, baik dari aspek filosofis maupun aspek teknis akad/ kontraknya;

Ketiga, dalam praktik di lembaga keuangan syari'ah, khususnya perbankan masih banyak ditemukan adanya pembuatan kontrak bisnis syari'ah yang melanggar ketentuan aturan-aturan syari'ah, di antaranya, karena notaris yang menanganinya hanya berfungsi melegalisasi kontrak, tidak mengarahkan isi kontrak karena keterbatasannya;

Keempat, seiring dengan perluasan kompetensi peradilan agama untuk menyelesaikan dispute yang terjadi di lembaga keuangan syari'ah maka di-

${ }^{9}$ Adil, Mengenal Notaris Syari'ah, h. 5.

10 Ibid., h, 5-6. 
perlukan notaris-notaris yang cakap dalam merumuskan akad-akad/ kontrakkontrak bisnis syari'ah sehingga akan terwujud keseimbangan kemampuan (kompetensi) antara berbagai profesi hukum yang pada gilirannya akan mempengaruhi terhadap kualitas penegakan hukum Indonesia.

Istilah notaris syari'ah masih asing di telinga masyarakat, tetapi karena tuntutan zaman memerlukan akta notaris syari'ah sebagai back up dari notaris yang ada yang belum mengerti mengenai akad-akad syari'ah yang sering digunakan dalam perbankan syari'ah sementara mereka sering menjadi saksi dalam transaksi perbankan syari'ah. Karena itu, di dalam diskursus fikih dikenal satu kaidah yang sangat popular, yaitu taghayyur al-aḥkām bi 'l-taghayyuri alamkān wa al-azmān ${ }^{11}$ (perubahan hukum selaras dengan perubahan tempat dan zaman atau masa). Dulu memang notaris syari'ah kurang begitu penting, tetapi karena perkembangan zaman dengan semakin maraknya perbankan syari'ah di Indonesia, maka kehadiran notaris syari'ah sangat dinantikan.

Pada saat ini perkembangan dan pertumbuhan bisnis syari'ah di Indonesia sangat pesat. Kondisi ini meniscayakan adanya dukungan dari para profesional hukum untuk mengawal dan mendukung keberlanjutan perkembangan bisnis tersebut. Bidang hukum yang sangat mendukung dalam proses akad atau transaksi bisnis adalah notaris. Akan tetapi, keberadaan notaris yang memahami secara mendalam aspek bisnis syari'ah pada saat ini masih langka, kalaupun ada, masih terkesan amatiran. Oleh karena itu, gagasan untuk mengagas notaris syari'ah dalam hal ini adalah cukup menarik dan urgen, bahkan, berdasarkan peraturan perundang-undangan yang saat ini ada dan mengatur tentang notaris bisa memungkinkan berkembangnya notaris syari'ah. Namun demikian, notaris syari'ah yang nilai-nilai dasar filosofis dan yuridisnya digali dari alQur'an dan al-Sunnah sangat memungkinkan untuk dijadikan sumber hukum dalam pembentukan hukum formil di Indonesia karena hasil pemahaman dari keduanya dapat dikategorikan sebagai doktirn dalam istilah ilmu hukum. Akan tetapi, sebuah doktirn baru akan menjadi undang-undang atau hukum yang mengikat jika dalam pembentukannya memiliki landasan filosofis yuridis dan sosiologis yang jelas dan sesuai dengan falsafah hidup masyarakat Indonesia,

\footnotetext{
11Adil, "Pandangan Hugo de Groot, Thomas Hobbes dan Immanuel Kant terhadap Pernikahan di Bawah Umur”, makalah, Pasca Sarjana Universitas Muhammadiyah Jakarta, 2008, h. 13.
} 
yaitu berdasarkan landasan ideologi Pancasila dan landasan konstitusional, Undang-Undang Dasar Negara Republik Indonesia Tahun 1945. ${ }^{12}$ Oleh karena dalam tulisan ini penulis menawarkan konsep kebutuhan notaris syari'ah di Indonesia.

Berdasarkan uraian latar belakang di atas, maka dapat dirumuskan batasan permasalahan dalam penulisan ini adalah sebagai berikut: 1) Apa pengertian dari notaris dan dasar hukumnya? 2) Bagaimana perkembangan bisnis syari'ah di Indonesia? 3) Bagaimana urgensi kebutuhan notaris syari'ah di Indonesia? Pada dasarnya setiap penulisan karya ilmiah mempunyai tujuan tertentu yang hendak dicapai oleh penulis itu sendiri dan diharapkan mendapat penyelesaian yang baik atas segala masalah yang terjadi. Dalam penulisan ini tujuan yang hendak penulis capai yaitu: 1) Untuk mengetahui dan menganalisa dasar hukum dari notaris; 2) Untuk mengetahui dan menganalisa perkembangan bisnis syari'ah di Indonesia; 3) Untuk mengetahui dan menganalisa urgensi kebutuhan notaris syari'ah di Indonesia.

Kegunaan penelitian ini dapat ditinjau dari dua segi yang saling berkaitan yakni dari segi teoritis dan segi praktis. ${ }^{13}$ 1) Secara Teoritis adalah: a) hasil penulisan ini diharapkan dapat dijadikan dasar dalam pengembangan ilmu hukum notaris, khususnya mengenai notaris syari'ah; b) hasil penulisan ini diharapkan dapat dijadikan dasar dalam pengembangan ilmu Hukum bisnis syari'ah; c) hasil penulisan ini diharapkan dapat menjadi pedoman dan literatur bahan bacaan bagi masyarakat pada umumnya dan pemerintah pada khususnya tentang permasalahan notaris syari;ah dan hukum bisnis syari'ah. 2) Secara Praktis, a) bagi mahasiswa hukum, masyarakat, praktisi hukum, dan Pemerintah diharapkan agar penulisan ini dapat menjadi pedoman atau rujukan dalam menambah ilmu hukum notaris, khususnya mengenai notaris syari'ah; b) bagi masyarakat luas diharapkan agar penulisan ini dapat memberikan masukan dan pertimbangan dalam melakukan kegiatan dalam hukum bisnis syari'ah; c) bagi pihak-pihak yang berwenang dalam pengurusan bisnis syari'ah agar penulisan ini dapat mengurangi resiko timbulnya kesalahan dalam pengurusan tersebut dan dapat mempermudah cara administrasinya; d)

\footnotetext{
${ }^{12}$ Adil, Mengenal Notaris Syari'ah, h. 6-7.

${ }^{13}$ Nawawi, Hadari dan H.M. Martini, Instrumen Pendekatan Sosial, Suatu Pendekatan Proposal (Yogyakarta: UGM Press, 2007), h. 25.
} 
bagi penegak hukum diharapkan agar penulisan ini dapat memberikan sumbangan pemikiran dan bahan pertimbangan dalam mengambil keputusan terhadap sengketa hukum bisnis syari'ah apabila terjadi sengketa di Pengadilan; e) bagi pemerintah dan pembuat undang-undang diharapkan agar penulisan ini dapat memberikan masukan dalam pembaruan hukum sesuai perkembangan zaman sehingga tercapainya tujuan hukum untuk masyarakat Indonesia.

Metode penelitian yang penulis gunakan dalam penulisan ini, sehingga bisa mendapatkan sasaran dari tulisan ini adalah sebagai berikut: 1) Metode pendekatan, jenis penelitian yang digunakan dalam penelitian ini menggunakan metode pendekatan secara yuridis normatif, yaitu penelitian yang bertujuan untuk meneliti asas-asas hukum, sistematika hukum, sejarah hukum, dan perbandingan hukum. ${ }^{14}$ Penelitian ini difokuskan untuk mengkaji dan meneliti materi hukum atau perundang-undangan, yang berlaku dan berkompeten untuk digunakan sebagai dasar dalam melakukan pemecahan masalah, sehingga langkah-langkah dalam penelitian ini menggunakan logika yuridis. Pendekatan terhadap hukum yang normatif mengidentifikasikan dan mengkonsepsikan hukum sebagai norma, kaidah, peraturan, undangundangan yang berlaku pada suatu waktu dan tempat tertentu sebagai produk dari suatu kekuasaan negara tertentu yang berdaulat. Dan dalam penelitian ini untuk menguji teori yang telah ada pada suatu situasi konkret; ${ }^{15}$ 2) Pendekatan masalah, nilai ilmiah suatu pemabahasan dan pemecahan masalah terhadap legal issue yang diteliti sangat tergantung kepada cara pendekatan (approach) yang digunakan. ${ }^{16}$ Sesuai dengan tipe penelitian yang digunakan yaitu yuridis normatif maka pendekatan masalah yang dilakukan adalah: a) Pendekatan perundang-undangan (statue approach), Pendekatan perundang-undangan merupakan suatu hal yang mutlak dalam penelitian yuridis normatif, karena yang akan diteliti adalah berbagai aturan hukum yang menjadi focus sekaligus 1.

${ }^{14}$ Soerjono Soekanto dan Sri Mamudji, Penelitian Hukum Normatif(Jakarta: Rajawali Pers, 2011), h.

${ }^{15}$ Ronny Hanitijo Sumitro, Metodologi Penelitian Hukum dan Jurimetri (Jakarta: Ghalmia Indonesia, 1990), h. 23.

16Johny Ibrahim, Teori dan Metodologi Penelitian Hukum Normatif(Malang: Bayu Media Publishing, 2009), h. 299. 
tema sentral suatu penelitian. ${ }^{17}$ Pendekatan perundang-undangan dilakukan dengan menelaah semua undang-undang dan regulasi yang bersangkut paut dengan isu hukum yang sedang ditangani; b). Pendekatan historis (historical approach). Pendekatan historis dilakukan dalam kerangka pelacakan sejarah lembaga hukum dari waktu ke waktu. Pendekatan ini sangat membantu peneliti untuk memahami filosofi dari aturan hukum dari waktu ke waktu. Disamping itu, melalui pendekatan demikian penelitian ini juga dapat memahami perubahan dan perkembangan filosofi yang melandasi aturan hukum tersebut.18 Penelitian normatif yang menggunakan pendekatan sejarah memungkinkan seseorang peneliti untuk memahami hukum secara lebih mendalam tentang suatu pengaturan hukum tertentu sehingga dapat memperkecil kekeliruan, baik dalam pemahaman maupun penerapan suatu lembaga atau ketentuan hukum tertentu19; 3) Jenis dan sumber data, dalam penelitian ini, data yang digunakan yaitu Data Sekunder, Data sekunder yaitu data yang sudah diolah dan diperoleh dari penelitian perpustakaan (library research) terhadap dokumen-dokumen yang ada terutama bahan hukum sebagai berikut: a) bahan hukum Primer, bahan hukum primer yaitu bahan penelitian yang berasal dari perundang-undangan yang berkaitan dengan judul dan permasalahan yang dirumuskan; b) bahan hukum sekunder, bahan hukum sekunder yaitu bahan penelitian yang berasal dari literatur, makalah atau jurnal hukum, teori-teori ataupun pendapat dari para ahli hukum yang memberikan penjelasanpenjelasan atau keterangan-keterangan mengenai peraturan perundangundangan ${ }^{20}$; c) Bahan hukum tersier, bahan hukum tersier yaitu bahan yang memberikan petunjuk maupun penjelasan terhadap bahan hukum primer dan bahan hukum sekunder yang terdiri dari: kamus; ensiklopedia dan dokumendokumen lain yang berhubungan dengan objek penelitian untuk diterapkan dalam penulisan ini; 4) Metode pengumpulan data, bahan hukum yang bermanfaat bagi penulisan ini diperoleh data dengan cara studi dokumen atau bahan pustaka, yaitu teknik pengumpulan bahan hukum dari buku-buku,

\footnotetext{
17Peter Mahmud Marzuki, Penelitian Hukum (Jakarta: Kencana Prenada Media Group, 2005), h. 93.

18Ibid., h. 126.

${ }^{19}$ Satjipto Raharjo, Ilmu Hukum (Bandung: Alumni Bandung, 1986), h. 332.

20Soerjono Soekanto, Pengantar Penelitian Hukum (Jakarta: UI Press, 1986), h. 12.
} 
peraturan perundang-undangan, atau data-data tertulis lainnya yang berhubungan dengan permasalahan yang penulis dapatkan dilapangan. ${ }^{21}$ Sedangkan pengolahan dan analisis data, setelah data terkumpul maka langkah selanjutnya adalah pengolahan dan analisa data. Adapun bahan hukum yang telah diperoleh dari penelitian studi kepustakaan, akan diolah dan dianalisis secara kualitatif, yakni analisa data dengan cara menganalisis, menafsirkan, menarik kesimpulan sesuai dengan permasalahan yang dibahas, dan menuangkannya dalam bentuk kalimat-kalimat ${ }^{22}$ dan hasil analisa tersebut menjadi suatu karya tulis berbentuk karya ilmiah.

Mengingat penelitian merupakan suatu sarana pokok dalam pengembangan ilmu pengetahuan maupun teknologi. David H. Penny berpendapat bahwa penelitian adalah pemikiran yang sistematis mengenai berbagai jenis masalah yang pemecahannya memerlukan pengumpulan dan penafsiran fakta-fakta. Sedangkan J. Suprapto MA berpendapat bahwa penelitian ialah penyelidikan dari suatu bidang ilmu pengetahuan yang dijalankan untuk memperoleh faktafakta atau prinsip-prinsip dengan sabar, hati-hati serta sistematis. ${ }^{23}$ Metode merupakan suatu prosedur atau cara untuk mengetahui sesuatu, yang mempunyai langkah-langkah sistematis. ${ }^{24}$ Menurut Soerjono Soekanto metodologi pada hakikatnya memberikan pedoman tentang tata cara seorang ilmuwan dalam mempelajari, menganalisa, dan memahami lingkungan-lingkungan yang dihadapinya. ${ }^{25}$ Jadi yang dimaksud metode penelitian adalah prosedur mengenai cara-cara melaksanakan penelitian (yaitu meliputi kegiatan-kegiatan mencari, mencatat, merumuskan, menganalisis, sampai menyusun laporannya) berdasarkan fakta-fakta atau gejala-gejala secara ilmiah.

\section{B. Review Pustaka}

Untuk mengupas tuntas mengenai keberadaan notaris di dalam bisnis pasar modal syari'ah di Indonesia maka penulis mencoba memakai teori

21Ibid., h. 68.

22Mardalis, Metode Penelitian Suatu Pendekatan Proposal (Jakarta: Bumi Aksara, 2010), h. 83.

${ }^{23}$ Cholid Narbuko dan Abu Achmadi, Metodologi Penelitian (Jakarta: Bumi Aksara, 2002), h.1.

${ }^{24}$ Husaini Usman dan Purnomo Setiady Akbar, Metodologi Penelitian Sosial (Jakarta: Bumi Aksara, 2003), h. 42.

${ }^{25}$ Soerjono Soekanto, Pengantar Penelitian Hukum, h. 6. 
kepastian hukum. Menurut Soerjono Soekanto, wujud dari kepastian hukum adalah perturan-peraturan dari pemerintah pusat yang berlaku umum di seluruh wilayah negara. Kemungkinan lain adalah peraturan tersebut berlaku umum, tetapi bagi golongan tertentu dapat pula peraturan setempat, yaitu peraturan yang dibuat oleh penguasa setempat yang hanya berlaku di daerahnya saja. ${ }^{26}$ Teori kepastian hukum menurut Van Apeldoorn adalah dapat ditentukan hukum apa yang berlaku untuk masalah-masalah yang konkret. Dengan dapat ditentukannya peraturan hukum untuk masalah-masalah yang konkret, pihak-pihak yang berperkara sudah dapat mengetahui sejak awal ketentuan-ketentuan apakah yang akan dipergunakan dalam penyelesaian sengketa tersebut. Kemudian kepastian hukum berarti perlindungan hukum. ${ }^{27}$

Teori kepastian hukum mengandung 2 (dua) pengertian yaitu: ${ }^{28}$ 1) Adanya aturan yang bersifat umum membuat individu mengetahui perbuatan apa yang boleh atau tidak boleh dilakukan; 2) Berupa keamanan hukum bagi individu dari kesewenangan pemerintah karena dengan adanya aturan hukum yang bersifat umum itu individu dapat mengetahui apa saja yang boleh dibebankan atau dilakukan oleh negara terhadap individu. Kepastian hukum bukan hanya berupa pasal-pasal dalam undang-undang melainkan juga adanya konsistensi dalam putusan hakim antara putusan hakim yang stau dengan putusan hakim lainnya untuk kasus yang serupa yang telah diputuskan. Sedangkan arti penting kepastian hukum menurut Soedikno Mertokusumo bahwa masyarakat mengharapkan adanya kepastian hukum karena dengan adanya kepastian hukum, masyarakat akan lebih tertib. Hukum bertugas menciptakan kepastian hukum karena bertujuan untuk ketertiban masyarakat. Tanpa kepastian hukum, orang tidak tahu apa yang harus diperbuatnya sehingga akhirnya timbul keresahan. Tetapi jika terlalu menitik beratkan pada kepastian hukum dan ketat menaati peraturan hukum, maka akibatnya akan kaku serta menimbulkan rasa tidak adil. Apapun yang terjadi peraturannya tetap demikian, sehingga harus ditaati dan dilaksanakan. Undang-Undang itu sering terasa kejam apabila dilaksanakan secara ketat. ${ }^{29}$

\footnotetext{
${ }^{26}$ Soerjono Soekanto, Beberapa Masalah Hukum dalam Kerangka Pembangunan di Indonesia (Jakarta: UI Press, 2006), h. 155.

27Peter Mahmud Marzuki, Penelitian Hukum, h. 60.

28Ibid., h. 158.

${ }^{29}$ Sudikno Mertokusumo, Hukum Acara Perdata Indonesia (Yogyakarta: Liberty, 2006), h. 136.
} 
Melalui teori kepastian yang dijelaskan di atas, menurut penulis dengan adanya kepastian yang jelas mengenai notaris syari'ah, seiring dengan perkembangan pesat bisnis syari'ah di Indonesia, maka menurut penulis harus ada yang pengaturan yang lebih lanjut dalam menyikapi hal ini, dimana pemerintah harus segera membuat aturan yang jelas mengenai notaris syari'ah yang mendukung perekonomian Indonesia.

Selain itu untuk mendukung tulisan ini, sebelumnya sudah juga tulisan yang menyinggung mengenai notaris syari'ah ini, yaitu tulisan dari Yulies Tiena Masriani di dalam Jurnal Ilmiah Serat Acitya Universitas Tujuh Belas Agustus Semarang, dengan judul bahasan "Kedudukan Hukum Akta-akta Notaris dalam Ekonomi Islam". Dimana Yulies Tiena Masriani memiliki rumusan masalah antara lain makna dan fungsi akad notaris dalam hukum syari'ah, prinsip hukum kontrak barat, prinsip kontrak hukum Islam dan akta otentik notaris. Maka dengan adanya pembahasan yang mendekati dengan tulisan ini, semoga hal itu dapat menjadi rujukan dan juga sebagai pembeda dalam penulisan ini, sehingga menyajikan tulisan-tulisan yang dapat mendukung keberadaan notaris syari'ah di Indonesia.

\section{Apa Itu Notaris?}

Sebagai negara hukum yang berdasarkan pada Pancasila dan UndangUndang Dasar Negara Republik Indonesia Tahun 1945, Negara Kesatuan Republik Indonesia wajib melaksanakan penegakan hukum yang mencerminkan keadilan, kepastian dan kemanfaatan sebesar-besarnya demi tujuan perlindungan hukum, ketertiban dan kesejahteraan rakyat. Guna menunjang keberhasilan penegakan hukum itu, dibutuhkan alat bukti otentik mengenai keadaan, peristiwa, atau perbuatan hukum yang dilaksanakan melalui jabatan tertentu, yaitu oleh notaris sebagai pejabat umum. ${ }^{30}$

Lembaga notaris yang ada di Indonesia ini bukan lembaga yang lahir dari bumi Indonesia. Negara kita menganut jenis notaris yang civil law, cirinya adalah diangkat oleh penguasa yang berwenang; bertujuan melayani kepentingan

\footnotetext{
${ }^{30}$ Endang Purwaningsih, "Penegakan Hukum Jabatan Notaris dalam Pembuatan Perjanjian Berdasarkan Pancasila dalam Rangka Kepastian Hukum”, Jurnal Adil, Vol. 2. No. 3, 2011, h. 52.
} 
masyarakat umum dan mendapatkan honorarium dari masyarakat umum. Sebagai dasar hukum didirikannya lembaga notaris pada tanggal 26 Januari 1860, dengan ditebitkannya peraturan Notaris Reglement yang selanjutnya dikenal dengan Peraturan Jabatan Notaris. Reglement atau ketentuan ini bisa dibilang adalah kopian dari Notariswet yang berlaku di Belanda. Peraturan jabatan notaris terdiri dari 66 pasal, peratura jabatan notaris ini masih berlaku sampai dengan diundangkannya Undang-Undang No. 30 Tahun 2004 tentang Jabatan Notaris ${ }^{31}$, yang akhirnya kembali dirubah menjadi Undang-Undang No. 2 Tahun 2014 tentang Pengganti Undang-Undang No. 30 Tahun 2004 tentang Jabatan Notaris.

Kehadiran lembaga notaris ini sengaja diciptakan negara sebagai implementasi dari negara memberikan pelayanan kepada rakyat, khususnya dalam pembuatan akta otentik yang diakui oleh negara. Lebih jauh lagi jika dapat diartikan notaris adalah pejabat umum yang berwenang untuk membuat akta otentik dan kewenangan lainnya sebagaimana dimaksud dalam UndangUndang No. 2 Tahun 2014 pengganti Undang-Undang No. 30 Tahun 2004 tentang Jabatan Notaris. Dalam rangka melaksanakan amanah pasal tersebut, notaris mengemban tugas penting untuk melayani masyarakat. Pasal 4 Undang-Undang Jabatan Notaris menegaskan bahwa sebelum menjalankan jabatannya, notaris wajib mengucap sumpah atau janji menurut agamanya bahwa akan patuh dan setia kepada negara Republik Indonesia, Pancasila dan Undang-Undang Dasar Negara Republik Indonesia Tahun 1945, UndangUndang tentang Jabatan Notaris serta peraturan perundang-undangan lainnya serta akan menjalankan jabatan denagan amanah, jujur, sakasama, mandiri, tidak berpihak dan akan menjaga sikap, tingkah laku, akan menjalankan kewajiban sesuai dengan kode etik profesi, kehormatan, martabat dan tanggung jawab sebagai notaris, juga akan merahasiakan isi akta dan keterangan yang diperoleh dalam pelaksanaan jabatan notaris. ${ }^{32}$

\footnotetext{
${ }^{31}$ Aryani Witasari, "MPD Bukan Advokat Para Notaris Berdasarkan Undang-Undang Nomor 30 Tahun 2004 tentang Jabatan Notaris" Jurnal Hukum, Vol. XXVIII, No. 2, 2012, h. 884-885.

${ }^{32}$ Endang Purwaningsih, "Bentuk Pelanggaran Hukum Notaris di Wilayah Provinsi Banten dan Penegakan Hukumnya" Mimbar Hukum, Vol. 27, No. 1, 2015, h. 15.
} 
Notaris sebagai pejabat publik yang berwenang untuk membuat akta otentik, mempunyai peran penting dalam kehidupan masyarakat, banyak sektor kehidupan transaksi bisnis dari masyarakat yang memerlukan peran serta dari Notaris, bahkan beberapa ketentuan yang mengharuskan dibuat dengan Akta Notaris yang artinya jika tidak dibuat dengan Akta Notaris maka transaksi atau kegiatan tersebut tidak mempunyai kekuatan hukum. ${ }^{33}$ Jabatan yang dimiliki oleh seorang notaris adalah jabatan kepercayaan, dimana seseorang bersedia mempercayakan sesuatu kepadanya. Sebagai seorang kepercayaan, notaris memilik hak untuk merahasiakan semua yang diberitahukan kepadanya selaku notaris, sekalipun ada sebagaian yang tidak dicantumkan dalam akta. ${ }^{34}$

Notaris berperan melaksanakan tugas negara dalam bidang hukum keperdataan dan kepada notaris dikulifikasikan sebagai Pejabat Umum yang berwenang untuk membuat akta otentik dan akta merupakan formulasi keinginan atau kehendak para pihak yang dituangkan dalam akta notaris yang dibuat di hadapan atau oleh notaris dan kewenangan lainnya.

Notaris memiliki beberapa karakteristik tertentu, antara lain: ${ }^{35}$

1. Notaris merupakan suatu jabatan, jabatan notaris diadakan atau kehadirannya dikehendaki oleh aturan hukum dengan maksud untuk membantu dan melayani masyarakat yang membutuhkan alat bukti tertulis yang bersifat otentik mengenai keadaan, peristiwa atau perbuatan hukum. Aturan hukum yang dimaksud adalah Undang-Undang Jabatan Notaris, sehingga segala hal yang berkaitan notaris di Indonesia harus mengacu pada Undang-Undang Jabatan Notaris.

2. Notaris mempunyai kewenangan tertentu, kewenangan notaris tercantum di dalam Pasal 15 ayat (1), (2) dan (3) Undang-Undang Jabatan Notaris.

3. Diangkat dan diberhentikan oleh pemerintah, meskipun secara administratif diangkat dan diberhentikan oleh pemerintah, tidak berarti notaris menjadi subordinasi (bawahan) pemerintah, sehingga di dalam menjalankan jabatannya: 1) bersifat mandiri; 2) tidak memihak siapapun; 3) tidak

\footnotetext{
33Samuel Hutabarat, "Kewajiban dan Kewenangan Majelis Pengawas Notaris", Gloris Yuris, Vlo.6, No. 3, 2006, h. 87.

${ }^{34}$ Muhammad Ilham Arisaputra, "Kewajiban Notaris Dalam Menjaga Kerahasian Akta Dalam Kaitannya Dengan Hak Ingkar Notaris", Jurnal Perspektif, Vol. XVII, No. 3, 2012. h. 173.

${ }^{35}$ Aryani Witasari, “MPI Bukan Advokat Para Notaris ...” h. 885-886.
} 
tergantung kepada siapapun, yang akibatnya di dalam menjalankan tugas jabatannya tidak dapat dicampuri oleh pihak yang mengangkatnya atau oleh pihak lain.

4. Tidak menerima gaji atau pensiun dari yang mengangkatnya, notaris hanya menerima honorarium dari masyarakat yang telah dilayaninya atau dapat memberikan pelayanan cuma-cuma untuk mereka yang tidak mampu.

5. Akuntabilitas atas pekerjaannya kepada masyarakat, notaris memiliki tanggungjawab harus melayani masyarakat, masyarakat dapat menggugat notaris secara perdata, biaya ganti rugi serta bunganya, jika ternyata akta tersebut dapat dibuktikan dibuat tidak sesuai dengan aturan hukum yang berlaku.

Disamping memiliki karakteristik seperti tersebut di atas, notaris hanya berkedudukan di satu tenpat di kota atau kabupaten, dan memiliki kewenangan wilayah jabatan seluruh wilayah provinsi dari tempat kedudukannya. Notaris hanya memiliki 1 (satu) kantor, tidak boleh membuka cabang atau perwakilan dan tidak berwenang secara teratur menjalankan jabatan dari luar tempat kedudukannya, yang artinya seluruh pembuatan akta-akta tertentu. Notaris dapat membuat perserikatan perdata, dalam hal ini mendirikan kantor bersama notaris, dengan tetap memperhatikan kemandirian dan keneteralannya dalam menjalankan jabatan notaris. ${ }^{36}$ Setiap notaris dtempatkan di suatu daerah berdasarkan formasi notaris. Formasi notaris ditempatkan di tentukan oleh menteri Hukum dan Hak Asasi Manusia, dengan mempetimbangkan usul dari organisasi notaris yaitu Ikatan Notaris Indonesia. Dimana formasi ditentukan berdasarkan: kegiatan dunia usaha; jumlah penduduk dan rata-rata jumlah akta yang dibuat oleh dan/atau di hadapan notaris setiap bulannya.

Sejak berlakunya Undang-Undang Jabatan Notaris maka notaris berada di bawah kewenangan Menteri Hukum dan Hak Asasi Manusia, maka dari itu yang dapat mengangkat dan memberhentikan notaris adalah kewenangan dari Menteri Hukum dan Hak Asasi Manusia. Untuk dapat diangkatnya seseorang menjadi seorang notaris harus memenuhi persyaratan tertentu. Hal ini sesuai dengan ketentuan dalam Pasal 3 Perubahan Undang-Undang Jabatan Notaris,

36Aryani Witasari, “MPI Bukan Advokat Para Notaris ..." h. 886. 
yang menyatakan bahwa yang dapat diangkat menjadi notaris adalah warga negara Indonesia;

1. Bertakwa kepada Tuhan Yang Maha Esa;

2. Berumur paling sedikit 27 (dua puluh tujuh) tahun;

3. Sehat jasmani dan rohani yang dinyatakan dengan surat keterangan sehat dari dokter dan psikiater;

4. Berijazah sarjana hukum dan lulusan jenjang strata dua kenotariatan;

5. Telah menjalani magang atau nyata-nyata telah bekerja sebagai karyawan notaris dalam waktu paling singkat 24 (dua puluh empat) bulan berturutturut pada kantor notaris atas prakarsa sendiri atau atas rekomendasi organisasi notaris setelah lulus strata dua kenotariatan;

6. Tidak berstatus sebagai pegawai negeri, pejabat negara, advokat, atau tidak sedang memangku jabatan lain yang oleh undang-undang dilarang untuk dirangkap dengan jabatan notaris; dan

7. Tidak pernah dijatuhi pidana penjara berdasarkan putusan pengadilan yang telah memperoleh kekuatan hukum tetap karena melakukan tindak pidana yang diancam dengan pidana penjara 5 (lima) tahun atau lebih.

Setelah persyaratan untuk diangkatnya menjadi notaris telah terpenuhi, maka sebelum menjalankan jabatan wajib mengucapkan sumpah/janji menurut agamanya di hadapan menteri atau pejabat yang ditunjuk oleh menteri hukum dan hak asasi manusia. Pengucapan sumpah atau janji tersebut dilakukan paling lambat 60 hari. Jika tidak terpenuhi maka keputusan pengangkatan sebagai notaris dapat dibatalkan oleh menteri.

Hal ini sesuai dengan ketentuan Pasal 7 Perubahan Undang-Undang Jabatan Notaris dinyatakan bahwa dalam jangka waktu paling lamabat 60 (enam puluh) hari terhitung sejak tanggal pengambilan sumpah/janji jabatan notaris, yang bersangkutan wajib:

1. Menjalankan jabatannya dengan nyata;

2. Menyampaikan berita acara sumpah/janji jabatan notaris kepada Menteri, Organisasi Notaris, dan Majelis Pengawas Daerah; dan

3. Menyampaikan alamat kantor, contoh tanda tangan, dan paraf, serta teraan cap atau stempel jabatan notaris berwarna merah kepada menteri dan pejabat lain yang bertanggung jawab di bidang pertanahan, Organisasi 
Notaris, Ketua Pengadilan Negeri, Majelis Pengawas Daerah, serta Bupati/ Walikota di tempat notaris diangkat.

Di dalam melaksanakan tugasnya sebagai seorang pejabat notaris, notaris tidak pernah lepas dari hak, kewajiban serta larangan. Adapun hak notaris berupa:

1. hak untuk cuti (Pasal 25);

2. hak untuk mendapat honorarium (Pasal 36), dan

3. hak ingkar (Pasal 4, jo Pasal 16 huruf e jo Pasal 54)

Kewajiban notaris meliputi sebagai berikut: 37

1. Mengucapkan sumpah/janji sebelum menjalankan jabatannya (Pasal 4 ayat (1);

2. Wajib menjalankan jabatan secara nyata, menyampaikan berita acara sumpah atau janji jabatan, alamat kantor, contoh tanda tangan dan paraf serta teraan cap/stempel jabatan notaris (Pasal 7);

3. Bertindak jujur, bijaksana, mandiri, tidak berpihak; dan menjaga kepentingan pihak yang terkait dalam perbuatan hukum (Pasal 16 ayat (1) huruf a);

4. Membuat akta dalam bentuk minuta akta dan menyimpannya sebagai bagian dari protokol notaris (Pasal 16 ayat (1) huruf b);

5. Melekatkan surat dan dokumen serta sidik jari pengahadap pada minuta akta (Pasal 16 ayat (1) huruf c);

6. Mengeluarkan grosse akta, salinan akta, atau kutipan. akta, berdasarkan minuta akta (Pasal 16 ayat (1) huruf d);

7. Memberikan pelayanan sesuai dengan ketentuan perundang-undangan (Pasal 16 ayat (1) huruf e);

8. Merahasiakan segala sesuatu mengenai akta yang dibuatnya dan segala keterangan yang diperoleh guna pembuatan akta sesuai dengan sumpah/janji jabatan, kecuali undang-undang menentukan lain (Pasal 16 ayat (1) huruf f);

9. Menjilid akta (Pasal 16 ayat (1) huruf g);

10. Membuat daftar dari akta protes terhadap tidak dibayar atau tidak diterimanya surat berharga (Pasal 16 ayat (1) huruf h);

\footnotetext{
${ }^{37}$ Habib Adjie, Aspek Pertanggung Jawaban Notaris Dalam Pembuatan Akta (Bandung: Mandar Maju, 2011), h. 91-92.
} 
11. Membuat daftar akta yang berkenaan dengan wasiat menurut urutan waktu pembuatan akta tiap bulan (Pasal 16 ayat (1) huruf i);

12. Mengirimkan daftar akta ke daftar pusat wasiat departemen dalam waktu 5 (lima) hari pada minggu pertama tiap bulan berikutnya (Pasal 16 ayat (1) huruf j);

13. Mencatat dalam repertorium tanggal pengiriman daftar wasiat pada setiap akhir bulan (Pasal 16 ayat (1) huruf k);

14. Mempunyai cap/stempel yang memuat lambang negara republik indonesia dan pada ruang yang melingkarinya dituliskan nama, jabatan, dan tempat kedudukan yang bersangkutan (Pasal 16 ayat (1) hurufl);

15. Membacakan akta di hadapan penghadap (Pasal 16 ayat (1) huruf $\mathrm{m}$ );

16. Menerima magang calon notaris (Pasal 16 ayat (1) huruf $n$ );

17. Berkantor di tempat kedudukannya (Pasal 19 ayat (1), dan

18. Wajib memberikan jasa hukum kepada orang yang tidak mampu (Pasal 37).

Atas hal yang telah dijelaskan di atas maka usaha-usaha masyarakat dalam mencapai kehidupan yang lebih baik sangat bergantung pada usaha-usaha pemerintah dalam meningkatkan perekonomian negara. Apabila pemerintah berhasil meningkatakan perekonomian negara, maka semakin dapat diharapkan juga bahwa bagi anggota masyarakat akan semakin terbuka kemungkinan untuk meningkatkan taraf hidupnya. Salah satu langkah yang ditempuh pemerintah dalam meningkatkan taraf hidup dan memajukan kesejahteraan masyarakat adalah melaksanakan kebijakan pembangunan ekonomi yang lebih diarahkan kepada terwujudnya demokrasi ekonomi. Agar hal ini dapat terwujud sangat dibutuhkan pula peran aktif masyarakat dalam kegiatan pembangunan ekonomi pemerintah tidak mungkin dapat bekerja sendiei tanpa dukungan dan peran aktif masyarakat. ${ }^{38}$ Salah satu yang harus didukung pemerintah adalah perkembangan bisnis syari'ah di Indonesia saat ini.

\footnotetext{
${ }^{38}$ Henny Saida Flora, "Peran Notaris dalam Pembuatan Akta Pendirian dan Akta Perubahan Anggaran Dasar Koperasi”, Jurnal Saintech, Vol.06, No. 02, 2014, h. 59.
} 


\section{Perkembangan Bisnis Syari'ah di Indonesia}

Pertumbuhan aktivitas ekonomi masyarakat di berbagai bidang telah mendorong tumbuhnya sektor jasa keuangan yang begitu pesat. Pertumbuhan ini dapat dilihat baik dari segi kuantitas pelaku usaha maupun jenis layanan yang diatawarkan, seperti layanan jasa perbankan, jasa asuransi, jasa pembiayaan konsumen dan berbagai jenis layanan jasa keuangan lain seperti jual beli valuta asing, penukaran uang dan lain-lain. Regulasi dan kebijakan pemerintah di bidang jasa keuangan juga berjalan dinamis seiring perubahan dan perkembangan yang ada di masyarakat, bahkan cenderung mempermudah pertumbuhannya. Kondisi tersebut pada satu pihak sangat bermanafaat bagi kepentingan konsumen, karena kebutuhan yang diinginkan dapat terpenuhi serta semakin terbuka lebar kebebasan untuk memilih aneka jenis kualiats sektor jasa keuangan yang ditawarkan. ${ }^{39}$ Melalui pelaksanaan bauran pemasaran yang sesuai dengan harapan konsumen, diharapkan akan mampu memuaskan nasabah sehingga terbentuk loyalitas nasabah. Membentuk dan memelihara kepuasan nasabah adalah merupakan tuntutan yang harus dilaksanakan, karena pada dasarnya dengan terpeliharanya kepuasan nasabah maka pihak lembaga keuangan akan senantiasa mendapatkan keuntungan. ${ }^{40}$

Binis merupakan suatu unsur penting di dalam kehidupan masyarakat. Hampir semua orang terlibat di dalamnya. Semua membeli barang atau jasa untuk bisa hidup atau setidak-tidaknya bisa hidup lebih nyaman. Bisnis pada dasarnya berperan sebagai jalan bagi manusia untuk saling memenuhi keinginan dan kebutuhannya. Akan tetapi, masalah keinginan dan kebutuhan manusia tak terbatas sedangkan sumber daya yang tersedia terbatas. Maka dari itu, perlu adanya sistem ekonomi yang harus menjawab tiga pertanyaan dasar, yaitu: apa saja yang perlu diproduksi; bagaimana memproduksinya dan untuk siapa produksi itu.

Kata syari'ah (syari'at) bisa disebut al-shir'ah (mufrad dari sharī'ah) secara harfiah berarti jalan ke sumber air dan tempat orang-orang yang minum.

\footnotetext{
${ }^{39}$ Agus Satory, "Perjanjian Baku dan Perlindungan Konsumen Dalam Transaksi Bisnis Sektor Jasa Keuangan: Penerapan dan Implemetasinya di Indonesia”, Padjajaran Jurnal Ilmu Hukum, Vol. 2, No. 2, 2015, h. 270.

${ }^{40}$ Fazril, "Analisis Bauran Produk dan Loyalitas Nasabah Studi Kasus Pada Bank Nagari Cabang Solok", Jurnal Ekonomi, Vol. 4, No. 2, 2008, h. 27.
} 
Orang-orang Arab menggunakan istilah ini khusus pada jalan setapak menuju palung air yang tetap dan diberi tanda yang jelas terlohat mata. Kata ini dikeluarkan dari kata syara'syai yang artinya menjelaskan dan menyatakan sesuatu atau dikeluarkan dari kata al-shir'ah dan al-sharī'ah yang artinya suatu tempat yang menghubungkan sesuatu untuk sampai pada sumber air yang tidak ada habis-habisnya sehingga orang yang membutuhkannya, tidak perlu lagi butuh alat untuk mengambilnya. ${ }^{41}$

Dengan demikian, bisnis syari'ah adalah segala macam transaksi binis yang menghasilkan keuntungan (profit) dengan cara yang sesuai dengan nilai-nilai syari'ah, baik al-Qur'an maupun al-Hadis guna meningkatkan kesejahteraan dan kemaslahatan umat manusia. ${ }^{42}$ Dalam konteks Indonesia, istilah bisnis syari'ah kurang familiar dibandingkan dengan istilah ekonomi syari'ah. Hal ini terutama karena berdasarkan Undang-Undang No. 3 Tahun 2006 tentang Perubahan atas Undang-Undang nomor 7 Tahun 1989 tentang Peradilan Agama dan direvisi oleh Undang-Undang No. 50 Tahun 2009 disebutkan dalam Pasal 49, bahwa, pengadilan agama bertugas dan berwenang memriksa, memutus dan menyelesaikan perkara di tingkat pertama antara orang-orang beragama Islam di bidang: a) perkawinan, b) waris, c) wasiat, d) hibah, e) wakaf, f) zakat, g) infaq, h) shadaqah dan i) ekonomi syari'ah.

Kata ekonomi syari'ah yang menjadi salah satu wewenang absolut peradilan agama tersebut kemudian menjadi istilah yang popular, termasuk ketika dikaitkan dengan aspek kajian hukumnya, yaitu hukum ekonomi syari'ah. Hal ini misalnya tampak jelas ketika tim dari Mahkamah Agung Republik Indonesia membuat rancangan hukum terapan ekonomi Islam yang akan menjadi hukum materil di peradilan agama, istilah yang digunakan adalah kompilasi hukum ekonomi syari'ah. ${ }^{43}$ Namun demikian istilah bisnis syari'ah sebenarnya juga telah diperkenalkan oleh Undang-Undang No. 3 Tahun 2006 dan direvisi oleh Undang-Undang No. 50 Tahun 2009, yaitu dalam bagian Penjelasan Pasal 49 huruf i. Hanya saja bisnis syari'ah dalam pasal penjelasan tersebut merupakan

\footnotetext{
41Yusuf Qardawi, Membumikan Syari'at Islam (Surabaya: Dunia Ilmu, 1997), h. 1.

${ }^{42}$ Adil, Mengenal Notaris Syari'ah, h. 50.

${ }^{43}$ Ah. Azharudi Latif dan Nahrowi, Pengantar Hukum Bisnis: Pendekatan Hukum Positif dan Hukum Islma (Jakarta: Lemlit UIN, 2009), h. 11.
} 
bagian dari kegiatan ekonomi syari'ah. Ekonomi Islam sesungguhnya secara inheren merupakan konsekuensi dari kesempurnaan Islam itu sendiri. Islam haruslah dipeluk secara kāffah dan komprehensif oleh umatnya. Islam menuntut kepada umatnya untuk mewujudkan keislamannya dalam seluruh aspek kehidupannya. Sangat;ah tidak masuk akal, seorang Muslim yang menjalankan salat lima waktu, lalu dalam kesemptan lain ia juga melakukan transaksi keuangan atau bisnis yang menyimpang dari ajaran Islam. ${ }^{44}$

Berikut kutipan penjelasan Pasal huruf (i), yang dimaksud dengan ekonomi syari'ah adalah perbuatan atau kegiatan usaha yang dilaksanakan menurut prinsip syari'ah, antara lain, meliputi: a) bank syari'ah, b) lembaga keuangan mikro syariah, c) asuransi syari'ah, d) reasurasni syari'ah, e) reksadana syari'ah, f) obligasi syari'ah dan surat berjangka menengah syari'ah, g) sekuritas syari'ah, h) pembiayaan syari'ah, i) pegadaian syari'ah, j) dana pensiun lembaga keuangan syari'ah dan $\mathrm{k}$ ) bisnis syari'ah.

Dari paparan di atas jelas bahwa undang-undang tidak secara eksplisit menyebutkan istilah hukum ekonomi Islam atau hukum ekonomi syari'ah ditemukan dalam draft kompilasi hukum ekonomi syari'ah hasil kajian Tim dari Mahkamah Agung Republik Indonesia. Sementara itu, istilah hukum bisnis syria'ah belum ditemukan dalam penjelasan Pasal 49, yang merupakan salah satu bentuk kegiatan ekonomi syari'ah. Adapun kegiatan ekonomi syari'ah dalam undang-undang tersebut di atas lebih dimaksudkan pada kegiatan lembaga keuangan syari'ah yang masuk kategori kegiatan bisnis jasa, padahal kegiatan bisnis meliputi perdagangan, industri dan jasa. Ini berarti jasa merupakan salah satu kegiatan bisni. Sementara dalam penjelasan Pasal 49 di atas, yang terjadi adalah sebaliknya, bisnis syari'ah merupakan salah satu bentuk kegiatan ekonomi syari'ah (yang lebih berorientasi pada jasa lembaga keuangan syari'ah). 45

Di sini tampak bahwa binis syari'ah merupakan bagian dari ekonomi syari'ah, yaitu akad tijari. Hal ini senada dengan pendapat Zainudi Ali bahwa ekonomi syari'ah yang merupakan bagian dari sitem perekonomian syari'ah

${ }^{44}$ Mustafa Edwin Nasution, et-al, Pengenalan Eksklusif Ekonomi Islam (Jakarta: Kencana, 2006), h. 2.

${ }^{45}$ Adil, Mengenal Notaris Syari'ah, h. 53. 
memiliki karakteristik dan nilai-nilai yang berfokus pada amar ma'rūf nahi munkar yang berarti mengerjakan yang benar dan meninggalkan yang dilarang.46 Dan pada perkembangan sekarang hukum binis syari'ah yang pada umumnya dilaksanakan sebagai hukum diyanī murni telah menjadi hukum qadha't. Disebut qadha'̂̀ karena ia berhubungan dengan permasalahan yuridis. ${ }^{47}$

Secara garis besar, ruang lingkup kajian bisnis syari'ah mengkaji tentang akad-akad non bagi hasil jasa perbankan dan akad bagi hasil, dimana penulis akan mencoba menyajikannnya sebagai berikut:

1. Non-bagi Hasil Jasa Perbankan

a. Murabahah, adalah akad jual beli barabg dengan menyatakan harga perolehan dan keuntungan (margin) yang disepekati oleh penjual dan pembeli. ${ }^{48}$

b. Salam, merupakan bentuk jual beli dengan pembayaran di muka dan penyerahan barang di kemudian hari (advanced payement, forward buying atau future sales) dengan harga, spesifikasi, jumlah kulitas, tanggal dan tempat penyerahan yang jelas, serta disepakati sebelumnya dengan perjanjian. 49

c. Istișna, adalah memesan kepada perusahaan untuk memproduksi barang atau komoditas tertentu untuk pembeli atau pemesan. Jika perusahaan mengerjakan unuk memproduksi barang yang dipesan dengan bahan baku dari perusahaan, kontrak atau akad istisna muncul. Agar akad istișna menjadi sah, harga harus ditetapkan dari awal sesuai kesepakatan dan barang harus memiliki spesifikasi yang jelas yang telah disepakati bersama. Dalam istișna pembayaran dapat di muka, dicicil sampai selesai atau di belakang, serta istișna bisanya diaplikasikan untuk industri dan barang manufaktur. ${ }^{50}$

\footnotetext{
46Zainudin Ali, Hukum Ekonomi Syari'ah (Jakarta: Sinar Grafika, 2008), h. 2-3.

${ }^{47}$ Abdul Kadir, Hukum Bisnis Syari'ah dalam al-Qur'an (Jakarta: Amzah, 2010), h. 31. 161.

${ }^{48}$ Adiwarman Karim, Bank Islam: Analisis Fiqih dan Keuangan (Jakarta: III T Indonesia, 2003), h.

${ }^{49}$ Ascarya, Akad dan Produk Bank Syari'ah (Jakarta: Rajawali Pers, 2007), h. 38.

50Ibid., h. 90.
} 
d. Ijārah, bisa disebut sewa, jasa atau imbalan. Dimana ijarah memiliki pengertian adalah akad yang dilakukan atas suatu dasar manfaat dengan imbalan jasa, ijārah dapat diapakai sebagai pembiayaan. Individu yang membutuhkan pembiayaan untuk membeli asset dapat mendatangi pemili dana (dalam hal ini bank) untuk membiayai pembelian asset produktif. Pemilik dana kemudian membeli barang dimaksud dan menyewakannya kepada yang membutuhkan aset tersebut. ${ }^{51}$

e. Ijārah wa iqtina, adalah transaksi sewa beli dengan perjanjian untuk menjual ataupun menghibahkan objek sewa pada akhir periode sehingga transaksi ini diakhiri dengan alih kepemilikan objek sewa. Ijarah mempunyai kemiripan dengan leasing pada sistem keuangan konvensional karena keduanya terdapat pengalihan seuatu dari satu pihak kepada pihak lain atas dasar manfaat. ${ }^{2}$

f. Ujr, adalah imbalan yang diberikan atau yang diminta atas suatu pekerjaan yang dilakukan. Akad ujr diaplikasikan dalam produk-produk jasa keuangan bank syari'ah (fee based services), seperti untuk penggajian, penyewaan safe deposit box, penggunaan ATM dan sebagainya; ${ }^{53}$

g. Șarf adalah jual beli suatu valuta dengan valuta lain. Produk jasa perbankan yang menggunkan akad șarf adalah fasilitas penukaran uang (money changer). ${ }^{54}$

2. Bagi Hasil

a. Mudarabah, adalah persetujuan kongsi antara harta dari salah satu pihak dan kerja dari pihak lain. Menurut al-Mushlih dan al-Shawi, mudarabah adalah penyerahan modal uang kepada orang yang berniaga sehingga ia mendaptkan presntase keuntungan, selain itu menurut Chapra, muḍarabah juga adakalanya disebut qiraḍ. Di sini penyandang dana disebut muqarid. Pada umumnya mazhab Hanafiah, Hanabiliah dan Zaidiyah menggunakan istilah mudarabah sementara Malikiyah dan Syafiiyah lebih suka dengan istilah qirad.55

\footnotetext{
51 Ibid., h. 96.

52Ibid., h. 100.

53Ibid., h. 110.

${ }^{54}$ Adil, Mengenal Notaris Syari'ah, h. 57.

${ }^{55}$ Adiwarman Karim, Bank Islam: Analisis Fiqih dan Keuangan, h. 35.
} 
b. Musharakah, di dalam akad musharakah pihak-pihak yang bertransaksi saling mencampurkan asetnya (baik real assets maupun financial assets) menjadi satu kesatuan dan kemudian menanggung resiko bersama-sama untuk mendapatkan keuntungan. Di sini keuntungan dan kerugian ditanggung bersama sesuai dengan porsi modal. Karena itu, kontrak ini tidak memberikan kepastian pendapat (renturn), baik dari segi jumlah (amount) maupun waktu (timing)-nya. Musharakah dilandasi adanya keinginan para pihak yang belerja sama untuk meningkatkan nilai aset yang mereka miliki secara bersama-sama. Semua bentuk usaha yang melibatkan dua pihak atau lebih di mana mereka bersama-sama memadukan seluruh bentuk sumber daya, baik yang berwujud maupun tidak berwujud. ${ }^{56}$

c. Muzara'ah, ialah mengerjakan tanah (orang lain), sperti sawah atau lading dengan imbalan sebagian hasilnya (seperdua, sepertiga atau seperempat). Sedangkan biaya pengerjaan dan benihnya ditanggung pemilik tanah kemudian pembagian hasil dari tanaman pertanian itu dibagi sesusi dengan kesepakatan. Dalam kontrak ini juga pihak-pihak yang bertransaksi saling mencampurkan asetnya (baik real assets maupun financial assets) menjadi satu kesatuan keuntungan. Di sini keuntungan dan kerugian ditanggung bersama. Karena itu, kontrak ini tidak memberikan kepastian pendapatan (return), baik dari segi jumlah (amount) maupun waktu (timing)-nya.57

d. Musaqah, adalah bentuk kerja sama di mana pemilik tanah memberikan pohon atau tanaman kepada petani untuk dikelola atau disirami sementara pembagian hasilnya sesuai dengan kesepakatan antara dua belah pihak yang melakukan akad tersebut. Sama halnya dengan muzara'ah dalam musaqah juga pihak-pihak bertransaksi saling mencampurkan asetnya (baik real assets maupun financial assets) menjadi satu kesatuan dan kemudian menanggung resiko bersama-sama untuk mendapatkan keunntungan. ${ }^{58}$

\footnotetext{
${ }^{56}$ Adil, Mengenal Notaris Syari'ah, h. 59.

${ }^{57}$ Ibid.

58 Ibid.
} 
e. Mukhabarah, ialah mengerjakan tanah (orang lain), seperti sawah atau lading dengan imbalan sebagain hasilnya (seperdua, sepertiga atau seperempat). Sedangkan biaya pengerjaan dan benihnya ditanggung orang yang mengerjakan (petani). Pada akad ini juga kerugian dan keuntungan ditanggung bersama antara pemilik tanah dan penggarap tanah (petani). ${ }^{59}$

\section{E. Urgensi Kebutuhan Notaris Syari'ah di Indonesia}

Agar suatu perjanjian mendapat kekuatan hukum, maka harus tercatat di hadapan notaris. Karena itu, setiap bisnis termasuk didalamnya adalah bisnis syari'ah, selalau membutuhakan notaris sebagai pejabat yang membuat akta otentik sesuai dengan tugasnya yang diatur dalam Undaang-Undang Jabatan Notaris. Disamping itu, notaris juga diberi kewenangan untuki memberikan legal advice kepada kliennya agar mencapai hak dan kewajibannya sehingga transaksi yang diperjanjikan di hadapan notaris tidak cacat secara hukum. Kedudukan seorang notaris sebagai suatu fungsionaris dalam masyarakat hingga sekarang sirasakan masih disegani. Seorang notaris biasanya dianggap sebagai pejabat tempat seseorang dapat memperoleh nasihat yang boleh diandalakan. Segala sesuatu yang ditulis serta ditetapkannya (konstatir) adalah benar, ia adalah pembuat dokumen yang kuat dalam suatu proses hukum. 60

Semakin berkembangnya bisnis yang serba syari'ah, keberadaan notaris syari'ah yang paham betul tentang akad atau transaksi yang bernasiskan syari'ah sangat diperlukan. Jadi antara notaris dan bisnis konvensional dan juga bisnis syari'ah sangat berhubungan, laksana dua sisi mata uang yang tidak dipasahkan satu sama lain. 61

Kajian terhadap fenomena akan akta notaris dalam hukum binis syari'ah berarti adanya penggabungan dua kutub hukum, yaitu hukum perdata barat dan hukum perdata Islam. Fenomena ini tidak terlepas dengan makin eksistensi dan pengakuan terhadap hukum syari'ah di Indonesia yang notabene

\footnotetext{
${ }^{59} \mathrm{Ibid}$, , h. 60.

${ }^{60}$ Guntur Iskandar, "Kekuatan Pembuktian Akta Di Bawah Tangan Yang Disahkan dan Dibukukan Oleh Notaris", Jurnal Delicti, Vol. 22, No. 1, 2015, h. 54.

${ }^{61}$ Adil, Mengenal Notaris Syari'ah, h. 86.
} 
penduduknya mayoritas beragama Islam dengan mengedepankan prinsip muamalah secara khusus prinsip ini dikategorikan dalam 2 (dua) hal, menurut Fatturahman Djamil, antara lain pertama, hal-hal yang dilarang untuk dilakukan dalam kegiatan muamalah yaitu objek perdagangan atau perniagaan harus halāl dan țayyib menurut kerelaan atau kehendak ('an tarīịin) dan pengelolaan yang amanah. Konsep objek halal menekankan adanya unsur halal dan bukan berbisnis yang diharamkan oleh Islam seperti menjual minuman keras, najis, alat-perjudian dan lain-lain. Preferensi disandarkan berdasarkan norma hukum Islam, bukan sekedar memenuhi hasrat keuntungan semata. Di satu sisi yang dimaksud (al-ridä́liyyah) mengacu pada surat al-Nisa' ayat 29 dengan kalimat 'an tarādin minkum yang berarti saling rela kalian. Ketentuan ini menggarisbawahi bahwa dalam melakukan transaksi perniagaan harus didasarkan pada kerelaan antara masing-masing pihak. Dengan kata lain, adanya asas "tidak ada paksaaan" dalam proses transaksi dari pihak manapun. Selain itu, dalam pengurusan dana dalam berbisnis memilki nilai kejujuran dan amanah dalam mengurus sifat Nabi dan Rasul Muhammad SAW. ${ }^{62}$

Kedua, hal-hal dilarang untuk dilakukan diantaranya riba yaitu setiap tambahan dari pinjaman yang berasal dari kelebihan nilai pokok yang dipinjamkan yang diberikan kepada kreditur; takhir yaitu benda yang menjadi objek perniagaan itu tidak ada ditangan atau dimilki, tidak diketahui keberadaanya, tidak dapat diserahkan pada waktunya sehingga mengakibatkan debitur mengalami kerugian, penyesalan dan bahaya; tadlis yaitu penipuan atas adanya kecacatan dari barang yang diperjualbelikan.63

Menurut analisis Adil, beberapa peluang demi terwujudnya notaris syari'ah, yaitu: 64

1. Para notaris dan para stake holder kebayankan mereka sepakat untuk melahirkan notaris syari'ah, yaitu notaris mengerti akad atau binis syari'ah dan mereka lebih menjurus pada bidang-bidang syari'ah sehingga mereka paham betul tentang bentuk-bentuk sekaligus pengertian tentang akad

\footnotetext{
${ }^{62} Y u l i e s$ Tiena Masriani, "Kedudukan Hukum Akta-Akta Notaris Dalam Ekonomi Islam”, Jurnal Ilmiah Serat Acitya,Vol. 4, No. 1,2011, h. 38.

${ }^{63} \mathrm{Ibid}$., h. 39.

${ }^{64}$ Adil, Mengenal Notaris Syari'ah, h. 110-113.
} 
atau bisnis syari'ah. Ketika notaris sudah terpenuhi, maka tidak lagi ada kekhawatiran atau kecurigaan tentang kesalahan dalam menentukan akad dan juga meminimalisasi kesalahan dan pelanggaran-pelanggaran dalam akad atau bisnis. Dengan adanya consensus dari para pelaku sekaligus para stake holder demi terwujudnya notaris syari'ah, maka bukan hal yang mustahil akan lahir notaris syari'ah.

2. Mayoritas penduduk Indonesia sampai saat ini adalah Muslim. Ini adalah aset untuk menggarap pasar demi terwujudnya notaris syari'ah.

3. Seiring dengan berjalannya waktu, maka perkembangan bisnis syari’ah pun dari tahun ke tahun semakin meningkat dan berkembang. Dengan berkembanganya bisnis yang serba syari'ah, maka bukan tidak mungkin akan lahir notaris syari'ah karean notaris juga merupakan salah satu bentuk bisnis.

4. Lahirnya organisasi Forum Notaris Syari'ah (FNS) belakangan ini yang dikendarai oleh notaris senior Syaifuddi Arif, semakin mempertajam akan butuhnya notaris syari'ah.

5. Semakin mewacananya notaris syari'ah di kalangan LSM yang bergerak pada ekonomi syari'ah di antaranya Ikatan Ahli Ekonomi Syari'ah dan Masyarakat Ekonomi Syari'ah, Himpunan Sarjana Syari'ah Indonesia. Begitu juga dengan perguruan tinggi Islam, seperti Universitas Islam Negeri Syarif Hidayatullah Jakarta yang sering melakukan diskusi dan juga seminar tentang notaris syari'ah.

6. Masih mnimnya notaris yang paham tentang akad atau bisnis syari'ah memberi peluang untuk lahirnya notaris syari'ah.

7. Demi terwujudnya notaris syari'ah di Indonesia ada beberapa langkah yang mesti dilakukan, diantaranya: a) perlu dibuat suatu program pendidikan (setingkat S-1) untuk keahlian sebagai tenaga notaris syari'ah dan juga bisa bekerja sama dengan badan pelatihan tertentu agar diatur bahwa setiap notaris yang menangani perbankan syari'ah atau lembaga keuangan syari'ah wajib mengikuti uji pelatihan tersebut. Dengan demikian, notaris memiliki kesempatan untuk dapat menangani atau berkecimpung dalam ekonomi syari'ah sepanjang memiliki kompetensi tersebut; b) penyelanggaraan pendidikan magister kenotariatan pada kurikulumnya perlu menambahkan mater akad atau bisnis syari'ah. Semua ini dilakukan untuk 
dapat menyeimbangkan pemahaman hukum positif dan hukum syari'ah (khususnya mualamah maliyah) sehingga pada akhirnya juga memilik keinginan untuk berkontribusi dalam pengembangan ekonomi syari'ah tidak hanya sebatas kebutuhan pekerjaan; c) LSM yang bergerak pada ekonomi syari'ah dan juga perguuruan tinggi Islam bekerja sama dengan Majelis Ulama Indonesia dan juga Kementeria Agama untuk memberikan pelatihan atau pendidikan serta seminar kepada para notaris untuk mengenal akad atau bisnis syari'ah; d) LSM dan juga perguruan tinggi Islam merekomendasikan kepada DSN agar perbankan syari'ah mempersyaratkan kepada notaris yang akan menjadi mitranya harus pernah mengikuti pelatihan notaris syari'ah.

Dalam upaya melahirkan notaris syari'ah tidak semudah membalikkan telapak tangan. Ada beberapa tantangan yang ditemukan di lapangan, di antaranya:65

1. Tidak semua notaris dan juga ada beberapa stake holder dari lembaga bisnis syari'ah yang tidak sepakat dengan lahirnya notaris syari'ah. Mereka berbeda pendapat tentang notaris syari'ah itu sendiri. Ada yang beranggapan bahwa notaris saat ini sudah syari'ah; ada juga yang berpendapat bahwa notaris saat ini belum syari'ah karena mengambil sumber hukumnya dari hukum barat, tidak berdasarkan al-Qur'an dan lebih penting dikhawatirkan salahnya dalam menentukan akad yang mengakibatkan cacatnya sebuah akad karena ketidakpahaman notaris terhadap akad atau bisnis syari'ah.

2. Melahirkan notaris syari'ah harus melalui beberapa proses, diantaranya, melalui lembaga legislative sehingga berbentuk undang-undang. Bagaimana mau menjadi sebuah undang-undang sementara para notaris itu sendiri masih berbeda persepsi dengan lahirnya notaris syari'ah.

3. Dengan lahirnya notaris syari'ah, maka lahan notaris yang selama ini ada, akan terambil asetnya karean semakin banyaknya notaris yang ada, sementara aset semakin berkurang. Ini jelas bagi mereka bukan merupakan kabar gembira.

65Ibid., h. 113-114. 
4. Maraknya perbankan syari'ah, hanya sebatas topeng belaka. Mereka hanya menarik minta pasar sementara pada praktiknya mereka belum secara murni menerapka konsep syari'ah. Ini dilatar belakangi karena para banker syari'ah yang selama ini ada, mereka berasal dari perbankan konvensional, begitu juga masih banyaknya minat nasabah untuk berinvestasi di bank konvensional daripada di bank syari'ah.

Maka sudah sewajarnya urgensi terhadap notaris syari'ah yang fokus kepada bidang syari'ah harus diatur dengan jelas, sehingga nanti tidak terjadi kecemburuan sosial antar para notaris, karena selama ini notaris banyak berkecimpung di bisnis konvensional.

\section{F. Kesimpulan}

Notaris sebagai pejabat publik yang berwenang untuk membuat akta otentik, mempunyai peran penting dalam kehidupan masyarakat, banyak sektor kehidupan transaksi bisnis dari masyarakat yang memerlukan peran serta dari Notaris, bahkan beberapa ketentuan yang mengharuskan dibuat dengan Akta Notaris yang artinya jika tidak dibuat dengan Akta Notaris maka transaksi atau kegiatan tersebut tidak mempunyai kekuatan hukum. Salah satu perkembangan bisnis yang paling pesat di Indonesia adalah binis syari'ah, dimana pada saat ini setipa lini perekonomian di Indonesia marak dengan berbau syari'ah. Dengan jumlah penduduk mayoritas Muslim, maka ini menjadi pangsa pasar yang menarik, bagi para pelaku bisnis untuk menarik nasabah atau konsumen dalam bisnis syari'ah yang dimilikinya. Dengan ini tantangan untuk menjamin suatu transaksi yang autentik di mata hukum akibat dari bisnis syari'ah ini, maka sudah sewajarnya notaris syari'ah hadir di Indonesia, agar bisa fokus dalam membidangi bisnis syari'ah.

Melalui tulisan ini, penulis hendak merekomendasikan kepada pemerintah agar secepat mungkin mengatur mengenai notaris syari'ah, sehingga natinya tidak terjadi tumpang tindih meneganai notaris syari'ah ini, selain itu juga kepada Ikatan Notaris Indonesia, segera bersikap kritis mengenai hal ini, agar anggota-anggotanya para notaris di Indonesia, tidak saling sikut akibat kecemburuan dari akta-akta bisnis syari'ah, dan juga kepada para notaris tetaplah bekerja sesuai dengan aturan perundang-undangan dan kode etik jabatan notaris. $[\mathrm{w}]$ 


\section{BIBLIOGRAFI}

Adil, Mengenal Notaris Syari'ah, Bandung: Citra Aditya Bakti, 2011.

- "Pandangan hugo de Groot, Thomas Hobbes dan Immanuel Kant Terhadap Pernikahan di Bawah Umur", makalah, Jakarta, Pasca Sarjana Universitas Muhammadiyah Jakarta, 2008.

Adjie, Habib, Aspek Pertanggung Jawaban Notaris Dalam Pembuatan Akta, Bandung: Mandar Maju, 2011.

Ali, Zainudin, Hukum Ekonomi Syari'ah, Jakarta: Sinar Grafika, 2008.

Arisaputra, Muhammad Ilham, "Kewajiban Notaris Dalam Menjaga Kerahasian Akta Dalam Kaitannya Dengan Hak Ingkar Notaris", Jurnal Perspektif, Vol. XVII, No. 3, 2012.

Arliman S, Laurensius, Notaris dan Penegakan Hukum Oleh Hakim, Yogyakarta: Deepublish, 2015.

Ascarya, Akad dan Produk Bank Syari'ah Jakarta: Rajawali Pers, 2007.

Fazril, "Analisis Bauran Produk dan Loyalitas Nasabah Studi Kasus Pada Bank Nagari Cabang Solok", Jurnal Ekonomi, Vol. 4, No. 2, 2008.

Flora, Henny Saida, "Peran Notaris dalam Pembuatan Akta Pendirian dan Akta Perubahan Anggaran Dasar Koperasi”, Jurnal Saintech, Vol. 06, No. 02, 2014.

Hasan, M. Khabir dan Mervyn K. Lewis, Handbook of Islamic Banking, Great Britain: Edward Elgar Publisih Limited, 2007.

Huda, Nurul, et-al, Ekonomi Makro Islam, Pendekatan Teoritis, Jakarta: Kencana: 2008.

Hutabarat, Samuel "Kewajiban dan Kewenangan Majelis Pengawas Notaris", Gloris Yuris, Vlo. 6, No. 3, 2006.

Ibrahim, Johny, Teori dan Metodologi Penelitian Hukum Normatif, Malang: Bayu Media Publishing, 2009.

Iskandar, Guntur, "Kekuatan Pembuktian Akta Di Bawah Tangan Yang Disahkan dan Dibukukan Oleh Notaris", Jurnal Delicti, Vol. 22, No. 1, 2015.

Kadir, Abdul, Hukum Bisnis Syari'ah dalam Al-Qur'an, Jakarta: Amzah, 2010. 
Karim, Adiwarman, Bank Islam: Analisis Fiqih dan Keuangan, Jakarta: III T Indonesia, 2003.

Kholis, Nur, "Penegakan Syari'ah di Indonesia (Perspektif Ekonomi)", Jurnal Hukum Islam, Vol 5, No. 1, 2006.

Latif, Ah. Azharudi dan Nahrowi, Pengantar Hukum Bisnis: Pendekatan Hukum Positif dan Hukum Islma, Jakarta: Lemlit UIN, 2009.

Manan, Abdul, Aspek Hukum Dalam Penyelengaraan Investasi Di Pasar Modal Syari'ah Indonesia, Jakarta: Kencana, 2009.

Mardalis, Metode Penelitian Suatu Pendekatan Proposal, Jakarta: Bumi Aksara, 2010.

Marzuki, Peter Mahmud, Penelitian Hukum, Jakarta: Kencana Pranada Media Group, 2010.

Masriani, Yulies Tiena, "Kedudukan Hukum Akta-Akta Notaris Dalam Ekonomi Islam", Jurnal Ilmiah Serat Acitya,Vol. 4, No. 1, 2011.

Mertokusumo, Sudikno, Hukum Acara Perdata Indonesia, Yogyakarta: Liberty, 2006.

Nawawi, Hadari dan H. M. Martini, Instrumen Pendekatan Sosial, Suatu Pendekatan Proposal, Yogyakarta: UGM Press, 2007.

Narbuko, Cholid dan Abu Achmadi, Metodologi Penelitian, Jakarta: PT. Bumi Aksara, 2002.

Nasution, Mustafa Edwin et-al, Pengenalan Eksklusif Ekonomi Islam, Jakarta: Kencana, 2006.

Purwaningsih, Endang, "Penegakan Hukum Jabatan Notaris Dalam Pembuatan Perjanjian Berdasarkan Pancasila Dalam Rangka Kepastian Hukum", Jurnal Adil, Vol. 2. No. 3, 2011.

Yusuf Qardawi, Membumikan Syari'at Islam, Surabaya: Dunia Ilmu, 1997.

Raharjo, Satjipto, Ilmu Hukum, Bandung: Alumni Bandung, 1986.

Satory, Agus, "Perjanjian Baku dan Perlindungan Konsumen Dalam Transaksi Bisnis Sektor Jasa Keuangan: Penerapan dan Implemetasinya di Indonesia", Padjajaran Jurnal Ilmu Hukum, Vlo. 2, No. 2, 2015.

Soekanto, Soerjono, Pengantar Penelitian Hukum, (Jakarta: UI Press, 1986 Beberapa Masalah Hukum dalam Kerangka Pembangunan di Indonesia, Jakarta: UI Press, 2006. 
dan Sri Mamudji, Penelitian Hukum Normatif, Jakarta: Rajawali Pers, 2011.

Sumitro, Ronny Hanitijo, Metodologi Penelitian Hukum dan Jurimetri, Jakarta: Ghalmia Indonesia, 1990.

Tim Penyusun Himpunan Fatwa Dewan Syaraiah Nasional MUI, Edisi Revisi Tahun 2006, Jakarta: DNS MUI-BI, 2006.

Usman, Husaini dan Purnomo Setiady Akbar, Metodologi Penelitian Sosial, Jakarta: PT. Bumi Aksara, 2003.

Witasari, Aryani, "MPD Bukan Advokat Para Notaris Berdasarkan UndangUndang Nomor 30 Tahun 2004 Tentang Jabatan Notaris" Jurnal Hukum, Vol.XXVIII, No. 2, 2012. 